\title{
Academic Reform in Fractured Disciplines - On the Interaction of Bologna, New-Public-Management and the Dynamics of Disciplinary Development
}

\author{
Cathleen Grunert $^{1}$ (D) Katja Ludwig $^{1}$
}

Accepted: 27 August 2021 / Published online: 17 September 2021

(C) The Author(s) 2021

\begin{abstract}
At the intersection of science studies and higher education research, this contribution looks at the way in which the requirements of universities as organizations release development dynamics in academic disciplines and it analyses the interaction between discipline and organization. We will analyse German educational science, bearing in mind it is an example of disciplines that are fractured and consequently have little consensus in terms of fundamental theories and basic concepts. Firstly, we take on a quantitative approach and analyse the changes in degree courses at the structural level and the symbolic boundaries or conceptual distinctions following the transition to the Bachelor and Master system. Secondly, we take a close look at the negotiating processes and practices, as well as at the disciplinary orientations that determine these boundary shifts, using a qualitative approach that focuses on the actors. In group discussions with representatives of the German educational science at different universities it stood out that actors involved in course design are compelled to find an equilibrium between the demands of the discipline and those of the organization, and do so in very different ways. Finally, we discuss the extent to which close interaction between higher education reforms and academic disciplines can be figured out, particularly for disciplines seen as fractured and which do not have consensual common disciplinary standards.
\end{abstract}

Keywords Bologna reform - Academic disciplines · Educational science · Organization · Degree courses · Quantitative research · Qualitative research

Katja Ludwig

katja.ludwig@paedagogik.uni-halle.de

Cathleen Grunert

cathleen.grunert@paedagogik.uni-halle.de

1 Philosophische Fakultät III, Institut für Pädagogik, Arbeitsbereich Erziehungswissenschaft mit dem Schwerpunkt: Soziokulturelle Bedingungen von Erziehung und Bildung, Martin-LutherUniversität Halle-Wittenberg, Halle (Saale), Germany 


\section{Introduction}

More than 20 years ago, fundamental change to the structure of European Higher Education was given green light, as the Bologna declaration was ratified (Bologna Declaration 1999). The aim to create a European area of higher education and to promote its position in the international sphere set in motion a process that would alter the higher education system in most European countries. It was accompanied, not only in Germany, by a radical shift in university governance structures towards a New Public Management and tougher competition, cultivating at the same time the self-image of the entrepreneurial university. These dynamics of change - the starting point for the empirical analysis presented below - seldom leave scientific disciplines and their processes of development unscathed. As a matter of fact, they shape their design, which is in turn reflected in the degree courses.

Up to now, however, empirical research has rarely examined the transformation of university studies and their structural design in European Higher Education, bearing in mind the interaction between disciplinary and organizational development. In the DFG-funded research project 'Educational Science in the Bologna Process. Strategies and orientation frameworks in the reform of academic programmes', we have addressed precisely this desideratum taking up the example of Germany and educational science. However, our reflections on this have been limited mainly to the inner-disciplinary and German-speaking area. With this contribution, we now bring together the strands of our previous quantitative and qualitative findings and open them up for international discussion by focusing on the interlinkages between discipline and organization. For this purpose, we briefly examine the findings of the quantitative sub-study in this article in order to raise sensitivity for the heterogeneous course landscape in German educational science (cf. Grunert and Ludwig 2016; Grunert, Ludwig, and Hüfner 2020). These quantitative findings indicated a shift in disciplinary boundaries. We explored this in more detail in our qualitative sub-study and asked about the social micro-processes in organizations that generate these shifts. Here, the focus was on the negotiation practices of the discipline representatives at the universities involved in reorganizing degree programmes to fit the Bachelor and Master system. We use qualitative methods to analyse collective orientations and practices that are expressed in the process of developing new bachelor and master's degrees. In doing so, we focus on the way actors who design these degree courses mediate between disciplinary demands and organizational requirements and on the resulting consequences for the design process of the degree courses. Following the brief presentation of the quantitative findings, we present the types that we have reconstructed in more detail in this contribution. We thereby abstract the findings from the German specifics (cf. for this Ludwig and Grunert 2018; Ludwig 2019) and bring them up for discussion as potentially cross-disciplinary and internationally relevant problems in the negotiation of curricula in university contexts. 


\section{Theoretical Framework and State of Research}

In our research, we see scientific disciplines as forms of internal differentiation within the system of science by following concepts of systems theory (Stichweh 1994). They could be described as research and communication communities, bonded by common challenges and research methods, and hosted in specific institutions that are their organizational infrastructure (Stichweh 1994; Abbott 2001). In this perspective, the university is first and foremost the organization that provides scientific disciplines with space for research and theory development, and it also ensures the auto-reproduction of disciplines since they have the opportunity to design their own degree courses. At the same time, universities can be seen as organizations that are both part of the system of science and the education system (Stichweh 1994: 175ff.). They are hence governed by different system logics. The university as an organization can have an impact on each of the two systems in very different ways. As part of the education system it is directly responsible for producing degree courses and ensuring suitable infrastructures and academic staff. However, it is only indirectly responsible for the system of science. In other words, while members of the organization, particularly the academic staff, are active in both sub-systems, the organization itself is merely an asymmetric participant (Hechler and Pasternack 2012: 17). Academic actors, on the other side, are obliged to take on a twofold position in university as members of an organization, on the one hand, and of the scientific discipline, on the other, although one can assume that they identify themselves with their discipline more than with their university (cf. Pellert 1999; Musselin 2007; Klatetzki 2012).

Firstly, scientific disciplines are by no means static but rather dynamic entities in constant change. These changes are not solely determined by internal scientific dynamics of competing paradigms (cf. Kuhn 1989 [1962]: 26f., 196), but are also governed by the logics of professional fields, of politics and even of organization (Hofstetter and Schneuwly 2010: 679). Fligstein and McAdam (2011, 2012), who combine neo-institutionalist perspectives with Bourdieu's capital theory, refer to power dynamics in the scientific field and their contribution to preserving or altering the fabric of disciplines. In fact, they add the actor-related perspective we refer to in our research to the existing organization theory approach. We therefore see disciplinary processes of change as the result of isomorphous processes of adjustment to external constraints from a neo-institutional point of view (Meyer and Rowan 1977; DiMaggio and Powell 1983), but at the same time the need to focus on the actor level in the process. We do this by focusing on the strategic practices and leading orientations of the actors involved, who institutionalize and constantly modify external expectations, such as the implementation of the Bologna Reform.

Hence, changes to the discipline and course development are inextricably bound to the representatives of the disciplines as actors at their universities. They move about in their specific university, academic and educational contexts and they (can) refer to them in different ways when pursuing their own interests and academic orientations. 
Secondly, scientific disciplines are not structurally unified but they vary due to their specific entanglement with non-university occupational fields, the consensuality of their underlying disciplinary basic theories or their different approaches to research. All of this determines the space for manoeuvre disciplines have. Here, Ambrose et al. (2010) differentiate scientific disciplines heuristically between two poles. While "unified, insular, firmly policed disciplines" (ibid.: 47ff.) are marked externally by strong boundaries dictated by coherent and consensual theoretical, methodological and practice-related orientations, "fractured, porous, contested disciplines" (ibid.) have weak boundaries that result from plural positions on their theoretical, methodological and practice-related foundations (similar differentiations into hard and soft disciplines: e.g. Huber 1991; Stichweh 1994). Against this background and given its current state, educational science in Germany can be described as a "fractured discipline" (Keiner and Schauffler 2014). This is not only evident due to the plurality of theoretical positions, empirical approaches and field references, which result in many professional currents (Horn 2014: 27), but also due to the fact that there are discussions on the identity of this discipline since its inception and this seems to be a permanent feature (Grunert 2012). Even before the higher education reform of the 1990s, educational science was debating plural approaches to theory and research, and practice-related experience. This was particularly noticeable in the old diploma degree courses (first degree), which made little or no reference to a shared canon of disciplinary knowledge (Wagner-Winterhager 1990) despite bearing the title of Diplom-Erziehungswissenschaft (diploma in educational science). This can be explained by the hybrid status of German educational science, a consequence of its indeterminate practical relevance (Grunert 2012). There is no agreement on the potential significance of educational science for the concrete professional pedagogical practice, nor is there consensus on the fields to which it should specifically refer (Krüger 2012; Horn 2014). That said, models of purely observational science or pure science of action seem equally problematic for educational science. In other words: the discipline itself oscillates between the education system and the system of science (Luhmann 2002; Fuchs 2007). Due to its focus on education, which is a function of society, educational science is confronted with societal and political demands relevant to teacher training and other professional pedagogical fields, and with economic interests. Nevertheless, it also wants to be a genuine science. Other scientific disciplines also have this dilemma to various degrees, but as Bourdieu argues, a discipline's relative autonomy depends on its ability to withstand these pressures and accord them their own disciplinary logic (Bourdieu 1998). Only with the emergence of a recurring disciplinary standpoint distinguishing it from other scientific disciplines in how it faces challenges and deals with external demands its relative autonomy and demarcation can be proved. From this perspective, educational science as a fractured discipline shows little power for refracting external influences. This seems to stem from little agreement on theoretical, methodological and practice-related positions, from strong division into sub-disciplines and from the emergence of local academic cultures.

Last but not least, disciplinary 'boundary work', as symbolized, for example, by the labels used to describe degree courses, seems particularly "ambiguous, flexible, historically changing, contextually variable, internally inconsistent, and sometimes 
disputed" (Gieryn 1983: 792). Boundary work as a power struggle for "credibility, prestige, power, and material resources" (Gieryn 1994: 405) thus refers to - not unlike Bourdieu's considerations - the contentious assertion of interests and sovereignty in matters of interpretation in a scientific field (cf. Lamont and Molnár 2002; Beer and Koenig 2009). Boundary demarcations in this sense are the expression of a "social interest in claiming, expanding, protecting, monopolizing, usurping, denying, or restricting the cognitive authority of science" (ibid.).

The reform of European Higher Education triggered by the Bologna Declaration, which could be described as an "exogenous shock" to the academic field to quote Fligstein and McAdam (2011: 9), calls on representatives from all scientific disciplines to develop new degree courses in a concerted effort while complying with regulatory expectations from the organizational framework. Although it can be assumed that these reform processes are highly challenging for fractured disciplines in particular, they have rarely been the focus of systematic empirical research. Taking up the example of German educational science, we explore this process in a fractured discipline with exceedingly weak and contested boundaries. This is accompanied by the fact that the corpus of commonly accepted knowledge, which is of central importance for disciplinary self-reproduction (Stichweh 1994: 17), is by no means clearly delineated. Rather, this can be defined as one of the permanent fields of disciplinary boundary and identity work. As a consequence, curriculum design has been also a controversial issue since the implementation of educational science as an academic field of study in Germany (for an overview: Austermann et al. 2004; Horn 1999). Therefore, with recourse to the field-theoretical approach of Fligstein and McAdam $(2011,2012)$, a highly dynamic field can be assumed to emerge in the interplay of Bologna reform and the development of universities as organizations, in which the demand to develop new study programmes also requires new negotiation processes of sustainable curricula at the university sites. The reason for this is in particular the fact that - at least at the level of formal structure (Meyer and Rowan 1977) - there was a national framework for the study and examination regulations that governed the establishment of educational science study programmes prior to the Bologna reform. The German Society for Educational Science (GERA or DGfE) was significantly involved in its development as a disciplinary communication space. However, this framework has been replaced for all disciplines by a decentralised accreditation system, which also puts the significance and binding power of recommendations from disciplinary associations (e.g. DGfE 2010) to the test. Nevertheless, local academic cultures already existed before the Bologna reform, so the question arises to which points of reference and actor constellations the representatives of fractured disciplines like educational science now refer and how they "translate existing rules and resources into the production of local orders" (Fligstein and McAdam 2011: 11).

At the same time, the existing rules and local framework conditions have also changed with the development of universities towards New Public Management itself, so that they are increasingly becoming "normal organizations" (Heinze and Krücken 2012: 8). They have more and more instruments at their disposal to assert their own interests, e.g. through profile building, target agreements or the development of their own framework examination regulations (e.g. Teichler 2016; Hüther 
2012). This also allows them to exert more influence on the design of study programmes - e.g. by defining certain module sizes for all subjects at the university site or by expecting a specific profile building of the study programmes. With our question about the disciplinary processes of change due to the Bologna reform, however, we aim less at the universities as organizations in their "multi-layeredness" (Goldmann 2017: 150), but rather at how the representatives of the discipline use their space for manoeuvre in the design of study programmes at the interface of discipline and organization. So we focus on changes to the structure and course design, and on the negotiating processes of representatives of the discipline against the background of disciplinary orientations and organizational rule expectations, from the perspective of the actors.

At present there are hardly any studies that take such an actor-based perspective into account. In a broader sense, however, studies that ask about social microprocesses in organizations are connectable to our research question. For example, Jarzabkowski $(2003,2010)$ focuses on the role of strategic practices for continuity and change in organizations on the basis of a qualitative design at three British universities. She emphasizes that change processes cannot be attributed to the powerful influence of a single group (e.g. university management), but to the interactive and powerful relationships between different actors. Furthermore, Jarzabkowski shows that actors pursue similar goals of action, but that the way they do so differs according to the cultural and historically developed practices at the respective universities (ibid. 2010: 132). Other important empirical reference points are studies that understand curricula as social constructions and their development as socio-culturally embedded processes (cf. for example, Goodson 1997; Karseth 2006; Barraud and Mignot-Gérard 2005; Karseth and Solbrekke 2016). Based on a document analysis of the implementation of the Bologna requirements in the Norwegian higher education system, Karseth (2006) concludes that with the Bologna Process, employability and international mobility become the driving forces of curriculum development, whereas previously the focus was on disciplinary knowledge and knowledge production itself. Drawing on European policy texts related to curriculum elements, Karseth and Solbrekke (2016) highlight the increasing influence of external and political aspects on curriculum development in higher education, noting that "the academic profession looses power as well as legitimacy with regard to defining the core content and processes of teaching in higher education" (ibid.: 222).

Barraud and Mignot-Gérard (2005) also describe a similar process for the French higher education sector on the basis of expert interviews and document analyses. They emphasize that curriculum development in France has advanced from the domain of disciplines to the domain of university policy, so that curricula are no longer exclusively oriented towards the internal logic of the disciplines, which also entails a weakening of the disciplines themselves. On the other hand, however, Barraud and Mignot-Gerard note that "academics or disciplines representatives still show a great ability to bypass or even refuse to enforce the university policies" (ibid.: 9). Barraud and Mignot-Gerard attribute the extent of heterogeneity of study programmes in France after the Bologna reform to the different strategies of the disciplinary representatives at the respective university sites, "who try to increase the visibility and the notoriety of their own specialty" (ibid.: 12). Using the example of 
political science in Germany and on the basis of semi-structured interviews, Steinhardt (2015) elaborates a primacy of discipline orientation. She emphasizes the motive of expanding and preserving individual research interests of disciplinary representatives as a central moment of course development and reason for the heterogeneity of study programmes (similar to Hechler and Pasternack 2012: 28).

All in all, it can be summarized that only a few and in part rather older studies are available that focus on an actor-related perspective on the disciplinary processes of change against the background of the challenges posed by the Bologna Process and its knock-on effects. Thus, there is also a lack of a differentiated perspective on the consequences and dynamics that are to be expected especially for disciplines that, like educational science, can be described as fragmented. This study aims to address these desiderata.

\section{Data and Methods}

The first step towards describing the current state of the degree course landscape in educational science was to conduct a quantitative study that examined all of the degree courses related to educational science in German universities, using selected criteria. For this purpose, data was collected on the study programmes and module descriptions of such degree courses where an enrolment was possible in the first (winter) semester 2013/14. Structural data referring to the type of degree (bachelor's or master's), number of subjects, labels of the degree courses and ECTS credits were extracted. Based on a quantitative content analysis (Früh 2017), data was collected on the subject-related (e.g., basics of the discipline, research methods, research training projects) and practical (internships) content of the degree courses. ${ }^{1}$ This was repeated in later surveys for the winter semesters 2014/15 and 2018/19, allowing more recent data to be introduced into the quantitative sub-study, albeit the latter differs only marginally from the first survey (Grunert, Ludwig, and Hüfner 2020).

Univariate and bivariate data analysis was supplemented by a hierarchical cluster analysis using the Ward method (cf. Bortz 2005) in order to first of all divide degree courses into homogeneous groups comparatively similar in terms of content design but as distinct from each other as possible, and to subsequently work out different degree course patterns. The purpose of this step was to describe the structure of the degree courses and their orientation towards teaching the basics of the discipline, research methods and practical relevance. A similar procedure was carried out for the degree course landscape in sociological science in order to draw conclusions on the extent to which degree course transformations following the Bologna Reform have led to different disciplinary changes, thereby pointing to an "erosion of disciplinarity" (Ruhloff 2006: 33; Grunert and Ludwig 2016).

\footnotetext{
1 To ensure data reliability, we took statements from two coders in the same situation and compared them (Intercoder reliability, cf. Früh 2017: 114). Values for intercoder reliability: $\kappa_{\text {basics }}=.76$, $\kappa_{\text {methods }}=$ $.95, \kappa_{\text {training procjects }}=.83, \kappa_{\text {internships }}=.94$.
} 
To answer the research question about strategic practices and key orientations regarding the new degree courses, we carried out group discussions at various universities with actors who had accompanied the respective degree course implementation processes. Based on quantitative findings on degree course content, ten locations with highly diverse and contrasting course patterns were selected along the criteria: degree of specialization, affiliation of the study programmes to the clusters of the quantitative sub-study and number of study programmes for which educational science is responsible. These included sites that offer specialized degree courses and sites with a more general orientation towards the discipline as a whole, sites with a limited number of degree courses or smallscale programmes, and sites with a wide range of degree courses. The aim of this sampling was to gather a broad spectrum of individual cases. Willingness to take part in these group discussions was high, making the sample comply perfectly with our selection criteria. The composition of the groups was left up to the representatives of the discipline themselves. Depending on the location, the groups are composed of three to eight participants, mainly full professors, and in some cases also research assistants. They also represent a wide range of positions within academic self-administration (e.g. deans or degree course coordinators).

Group discussions were based on a procedure developed by Ralf Bohnsack (2010), which begins with an open question and leaves much room for participants to add content of their own. The script for discussion subsequently focused on experiences associated with the introduction of degree courses into universities and the design of their content. We used the documentary method of interpretation (Bohnsack, Pfaff and Weller 2010) to analyze the group discussions. This procedure makes it possible to reconstruct the strategic practices and guiding orientations for action that gave rise to specific practices at different university sites, to examine the relational differences in their position in the field of educational science and, ultimately, to condense them into types. In the first phase, the documentary method aims to reconstruct the collective orientations for action of each group by formulating and reflecting interpretation while comparing the different cases. The term of orientation in the Documentary Method refers to implicit, atheoretical knowledge that is "underlying practical action" and in this sense it is also thought as "the »modus operandi « or the »habitus « in the terms of Pierre Bourdieu" (Bohnsack 2010: 106). Comparative analysis allows for the gradual reconstruction of the components of the orientation framework common to all the cases. For example, a problem all cases have to deal with. Taking the practices and guiding orientations of actors for degree course design as a starting point, we can see that all cases have to deal with two key challenges - the heterogeneity of the discipline and the rule expectations by the university. Different collective orientations relevant to this problem - which guide actions of the representatives of the discipline as implicit orientation frameworks - can then be worked out and, in a comparative approach, clearly distinguished from one another. In the second phase, the sense-genetic type formation (Nohl 2010: 211-212), these orientation frameworks are abstracted from the individual case and condensed into types by means of contrastive comparisons. However, no overarching types of orientation frameworks could be identified for dealing with the two reconstructed 
core challenges - the heterogeneity of the discipline and the rule expectations by the university -, i.e. there was no pattern connecting them. For this reason, the collective orientations in dealing with both challenges were condensed into two sense-genetic type formations.

\section{Findings}

The following is a brief presentation of the quantitative findings. They provide insight into how the degree course landscape of educational science in Germany has evolved. We then take a closer look at the qualitative findings in order to focus in more detail on the strategic practices and guiding orientations in the course design process and their challenges in the organizational context of the university. This ultimately allows us to determine the interaction of discipline and organization more precisely.

\section{Quantitative Findings}

\section{The Structural Alignment of Degree Courses}

The quantitative findings made it particularly clear that the degree course landscape in educational science is currently very heterogeneous. This is reflected in the content and the structure of the degree courses.

The following passages are taken from the survey findings for the winter semester 2013/14. The case selection for the qualitative survey and the sociological comparison were also based on these findings. In some instances they are supplemented by references to the survey of the winter semester 2018/19 in order to indicate possible changes, although these tend to be marginal when it comes to the bigger picture (cf. for further details Grunert and Ludwig 2016; Grunert, Ludwig, and Hüfner 2020).

At the time of the survey, 63 universities and universities of education in Germany were offering major degree courses in educational science. In other words, university degree courses not geared to a teaching profession but to other pedagogical professions. The educational science organization units were mainly responsible for these courses. A total of 186 bachelor's and master's degree courses were offered. By winter semester 2018/19, this figure had risen to 194 degree courses at 64 universities. These new degree courses are primarily part of the master's level and by and large complement existing courses. From the outside, this seems to indicate consolidation in the aftermath of highly dynamic years of establishing new degree courses following the Bologna Reform. There is, however, still considerable movement within the existing degree courses in terms of content and structure. More than half of the courses analysed for 2013/14, for example, have undergone significant changes to their structure and/or content, while several have altered their degree course labels. 


\section{Labels of Degree Courses as Symbolic Demarcation}

It is therefore not unimportant to cast an eye on the labels used for degree course descriptions to indicate the content of a discipline, since these not only serve as orientation for students but also as symbols of disciplinary boundaries. The wording of educational science degree courses clearly reflects the discipline's much discussed heterogeneity. No less than 90 different degree course labels are used to describe 186 courses, a trend that continues to flourish. Among them are what can be understood as 'generalized' degree course labels variously entitled Educational Science(s) [Erziehungswissenschaft(en)], Pedagogy [Pädagogik] or Bildungswissenschaft(en ${ }^{2}$ or a combination of these terms. In Germany the terms 'pedagogy' (or educational theory) and 'educational science' are frequently used parallelly to describe the discipline, even in disciplinary historical approaches, while 'Bildungswissenschaft' has only recently found its way into labelling. This parallel use of the terms educational science, Bildungswissenschaft and pedagogy - individually, in combination or even in the singular or plural - makes symbolic demarcation somewhat vague and seems more like a form of internal disciplinary boundary-blurring (Beer and Koenig 2009) that confounds rather than sets boundaries.

This impression is more intense when special labels are added. It extends the spectrum of labels of educational science degree courses and includes those which refer to professional pedagogical fields of action or specific problems. Among these are 39 degree courses that broaden the terms educational science(s), Bildungswissenschaft(en) and pedagogy to include a special focus, such as social pedagogy [Sozialpädagogik] or organizational development [Organisationsentwicklung]. These courses are mostly located in the master's domain. On the other hand, 65 degree courses dispense altogether with an overarching disciplinary label, choosing a specific label instead. The selected labels of this group refer for the most part to the classic sub-disciplines of educational science in Germany, such as social pedagogy [Sozialpädagogik], special needs education [Sonderpädagogik] or adult education [Erwachsenenbildung], but also to more recent trends, such as early childhood education [Pädagogik der frühen Kindheit], which has only reached an academic level in Germany in the last decade. The latter now occupies a wider space in the academic field. In addition, there are degree courses with labels that refer to specialization in empirical educational research [Empirische Bildungsforschung] or management and organizational development, whose role as fields of study was negligible in German Diploma programmes prior to the Bologna Reform (Krüger et al. 2003).

On the whole, there is still the trend that specialized subject designations in the master's degree cover a wider range of issues than in the bachelor's degree.

\footnotetext{
${ }^{2}$ When translating it into English, Erziehungswissenschaft and Bildungswissenschaft would result in the same term: educational science, but in German there is an essential difference between Erziehung and Bildung (Biesta 2016: 833; Keiner 2015). In English both coincide in the word education.
} 


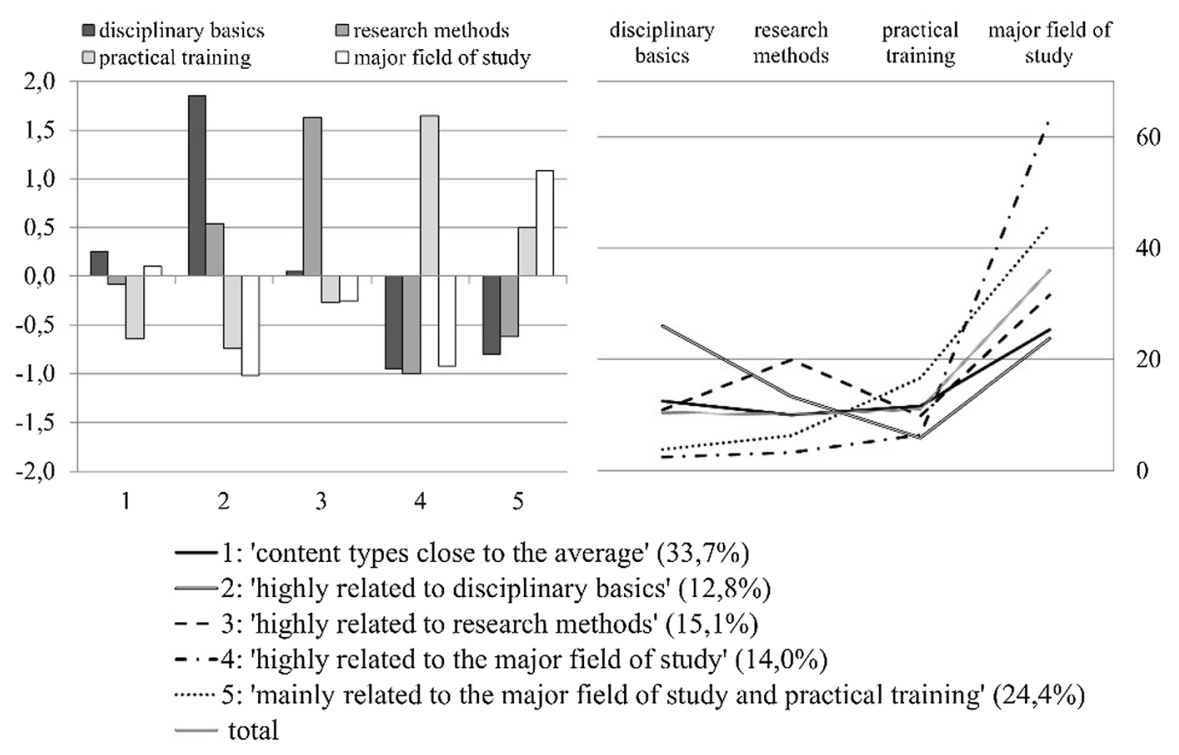

Fig. 1 Bachelor's degree course patterns ( $n=86$; left $z$-standardized deviations from mean value, right average percentage shares of the total volume of the study programmes)

\section{Degree Course Patterns}

The quantitative findings make it clear that German educational science is already quite heterogeneous at the level of symbolic demarcation via label designation. This is further proved by data analysis using Ward's hierarchical clustering method (cf. Bortz 2005). The aim was to differentiate the degree courses into groups that would be as homogeneous as possible in terms of their mandatory content of disciplinary basics, research methods, the major field of study and practical training. The cluster analysis is based on the percentage shares of the content types in the individual study programmes in relation to the average value for all degree programmes. The $\mathrm{z}$-standardized deviations from the mean value of the respective content rubrics shown in Figure 1 visualize well the characteristics of the clusters we found for the bachelor programmes. The results indicate that the study programmes differ greatly when it comes to the teaching of basic educational science, research methods, content of the major field of study, and practical training in their relations. The first group shows shared values in the four content types that are close to the mean value of all study programmes. The other clusters vary significantly from this and point to different priorities. While the second group of courses in the bachelor's degree shows a high incidence of disciplinary basics, little emphasis on research methods and even fewer practical references, the third group focuses heavily on research methods and far less on disciplinary principles and practice-oriented content. The fourth group in turn concentrates primarily on content related to the major field of study (z.B. social pedagogy, adult education, early education), while the fifth group works with a more balanced combination of content related to the major field of study and professional 
practice. In these two groups, disciplinary basics and research methods are significantly underrepresented (see Figure 1, based on Grunert, Ludwig, and Hüfner 2020: 40).

The cluster analysis clearly shows that a strong structural and content-related heterogeneity of degree courses in educational science can be assumed, through which disciplinary boundaries are blurred just as much as through the heterogeneous practice of their labelling. In the following, we will use the results of our qualitative substudy to explore the social micro-processes behind these boundary shifts.

\section{Qualitative Findings}

Educational science degree courses, after the study reform in Germany, already prove to be quantitatively heterogeneous as regards subject designation and the symbolic demarcation this expresses, and in regard to their content design and the interconnection between the different areas of study. Against this backdrop, the question arises: what are the underlying orientations of the university representatives of the discipline and what is the role of organizational frameworks?

Based on the comparative analysis of group discussions, two main 'habitual action' problems in the process of designing the degree programmes were identified across all cases. One deals with the heterogeneity of the discipline itself, in other words discovering how a fractured discipline, as reflected in the heterogeneous disciplinary positioning of the representatives of the discipline at the university, can arrive at a mutually accepted curriculum. With the development of new degree courses, the Bologna Reform virtually insists on a shared understanding of content and profiling, and presses for the orchestration of collective solutions in a discipline that is both fractured and anything but consensual. This habitual action problem was the basis for an initial sense-genetic type formation.

Group discussions also saw the emergence of a second significant habitual action problem, thereby placing the organizational side of curricular developments centre stage. These are clearly accompanied by university rule expectations that challenge the implementation of disciplinary orientations into the degree courses at universities. The strategies for action the representatives of the discipline use in response to organizational constraints thus form the basis for a second sense-genetic type formation across all cases.

Both type formations are presented below and followed by a discussion on the extent to which the coexistence of these two type formations is the result of tension between a fractured discipline and university as an organization (cf. for inner-disciplinary German discussion Ludwig and Grunert 2018; Ludwig 2019).

\section{Dealing with Disciplinary Heterogeneity (Sense-Genetic Type Formation I)}

The first sense-genetic type formation is linked to the cross-sample question of how different (sub-)disciplinary orientations in the collective practice of designing degree courses come into play as the expression of a fractured discipline and are 
negotiated as such. Comparative analyses led to the reconstruction of different forms of dealing with this problem of action. They have been condensed into three types.

The first type can be described as 'Establishing disciplinary standards'. Here, the external request for new degree course structures is used as an incentive to negotiate a basic agreement on course design. In addition, the choice of general subject designations should help draw symbolically strong disciplinary boundaries. The heterogeneity of educational science as a discipline as a whole is firmly established here on the negative counter-horizon, with educational science defined as a "synonym for different concepts ${ }^{3}$ " (S-location: 507f. ${ }^{4}$ ). In contrast, the collective orientation framework is characterized by shared understandings of educational science, which is tasked with curtailing fragmentation by setting standards. Representatives of the discipline see the reform as an opportunity "to concentrate on reaching a minimum agreement when introducing bachelor's degree courses" (D-location: 404ff.) and to design courses that reduce the perceived disciplinary heterogeneity of educational science, at least in their own university. Defining the degree course content is seen here as setting standards, which are either jointly negotiated or imposed by power.

A common understanding of the disciplinary essence of educational science was worked out at Location-D by negotiating specific topics and content:

Ew: We thought about what we wanted, what we wanted to pass on, what we wanted to convey, what the curriculum should look like, what's important to us, what is essential to educational knowledge and skills [...]. We had to work out a new degree course concept together. I can well remember discussions and definitions: is socialization part of this as a concept or is it not, is the notion of Bildung out of date or is it at the heart, is it the key concept of our discipline? [...] Of course we all had to sacrifice something in the debate because we had to find a compromise. [...] It was a struggle, of course it was a struggle (D-location: 210-244).

Several different academic perspectives and positions exist at this location, all of which were sounded out - in a process described as painful - before reaching a shared basic understanding of the core content of educational science. This type of content-based agreement regarding key definitions is not seen as a given, but must first be negotiated by the representatives of the discipline. Although negotiation outcomes are marked as a compromise, this demonstrates that reaching a disciplinary consensus even in a fractured discipline is not completely out of the question, at least on the level of singular university sites.

In the other case of this type, such a compromise is negotiated less collectively. In fact, it is the result of individual imposition by power. Enforcement of a specific disciplinary understanding based on interdisciplinarity and empirical research was

\footnotetext{
3 Unless otherwise indicated, direct quotations set in italics mark text passages from group discussions and are included here for the purpose of clarification. Names and places have been altered to ensure anonymity. These passages have been simplified in order to be read more easily and they have been translated from German into English.

4 This refers to line numbers in the respective group discussion transcripts.
} 
favoured by a generational change in the staff at the location concerned and was protected by human resources policies: "We tried to minimize heterogeneity [...] with appointment procedures [...] so that there's a sort of fit with a basic agreement across the college as a whole" (S-location: 1646ff).

The Bologna Reform and its demand for degree course development is thus negotiated in the 'Establishing disciplinary standards' type as a potential arena for setting site-specific standards and drawing boundaries that symbolize a common disciplinary understanding. Although the fractured nature of the discipline is perceived as problematic, it seems at least to be possible to work on it in each location. The educational science ideal as a scientific discipline nevertheless remains that of a discipline that is clearly recognizable both by its content and its tasks.

In contrast, the 'Anchoring disciplinary heterogeneity' type is characterized by a positive attitude to the heterogeneity of the discipline - both in terms of the discipline as a whole and of the academic staff at each site. 'Bildung' and Education as topics that are collectively considered relevant take centre stage, their paradigmatic and subject-related plurality is acknowledged and, where possible, firmly anchored in the degree courses.

Two type variants can be distinguished here. The 'Intra and interdisciplinary openness' variant highlights the discipline as both open and dynamic. Positionings outside the discipline, e.g. with psychology, are likewise acknowledged, which in turn can be interpreted as an expression of "interdisciplinary self-confidence" (Q-location: 1970). Demarcations from other disciplines, however, seem to be "less simple" (L-location: 155). Differences in the disciplinary positions of local representatives of the discipline regarding plural professional fields of action are considered necessary, "since professional activities do not evolve like a discipline" (Q-location: 1888f.). Degree course development is thus geared to both disciplinary and professional needs. Disciplinary heterogeneity is justified with external demands and explicitly included in the joint degree courses.

The 'Inner-disciplinary focus' variant in this type considers the low level of disciplinary contouring in educational science and the perceived blurring of boundaries to neighbouring disciplines to be problematic. Despite numerous differences in the details, a collectively shared position does exist in the discipline of educational science as a whole.

$B w:[. .$.$] I think much of what is worrying in educational science as a dis-$ cipline is reflected here. [...] I think educational science really does have a somewhat weak outline at the moment.

$[\ldots]$

Am:At times I wonder if the people we deal with and who have a professorship in the field genuinely think and argue from an educational science perspective or is it in fact sociological after all. (Y-location: 2861-2902)

Collectivization among the representatives of the different disciplines creates the orientation towards educational science as a relevant and relatively autonomous discipline, whose boundaries with neighbouring disciplines should be more clearly outlined. Inner-disciplinary heterogeneity is tolerated and degree course 
development linked to the goal of firmly establishing "the subject as a subject" (Y location: 848) in the curriculum. This means that degree course development should not be left to random site-specific configurations or purely individual interests. Instead, this is about the broad anchoring of general educational science content and the integration of diverse sub-disciplinary subject matters. Designing degree courses, however, is perceived in these cases as heavily influenced by external criteria and enmeshed in university management specifications, which are primarily geared to competition (e.g. subject designation or profiling), so that the successful assertion of disciplinary orientations does not live up to the ideal.

On the whole, the 'Anchoring disciplinary heterogeneity' type clearly indicates for the most part openness towards heterogeneous content and disciplinary orientations, which is reflected in the process of constructing degree courses. Nevertheless, while the fracturing of the discipline in the 'Intra and interdisciplinary openness' variant is considered necessary and not worrying, the 'Inner-disciplinary focus' variant regards blurry borders with neighbouring disciplines as negative.

The third type, 'Establishing sub-disciplinary autonomy', mostly shows evidence of movement towards autonomy when it comes to dealing with disciplinary heterogeneity in degree course design. Contrary to the two other types, there is little indication of a collective orientation towards the discipline as a whole, which leads to autonomous sub-disciplinary degree courses through different processes.

At the C-location, for example, prior to the introduction of bachelor's and master's degree programmes, sub-disciplinary autonomy was already common practice and, despite shared educational science principles, it culminated in different "branches" perceived "long before that" as separate degree courses. Coupled with this, the coexistence of contrasting disciplinary orientations called for the design of independent degree courses with different content, topics and sub-disciplinary references.

The Z-location likewise focuses primarily on sub-disciplinary content, although there is some evidence of common perspectives on the discipline as a whole.

Dw:Let's be honest, the bachelor's study the main subject without a major

Cm:yes

Bw:hmm ((quietly))

Dw:yes, they're studying a sub-discipline

[...]

Cm: yes that, too, because let's say, if you have to make concessions [...] then those aspects are completely marginal

Dw:yes

[...]

Cm: if you keep it broad, does that bring more((asking)) [...] what does it result in ((asking)), it's certainly not an overview

Dw:yes and there again apropos medicine and law I think we're too serious for that in our profession, I mean, they're going to be let loose upon people (Z-location: 1681-1714)

In conjunction with time constraints imposed by the Bachelor and Master system, disciplinary orientation towards specific sub-disciplinary fields of activity forces a 
departure from the content of the discipline as a whole during degree course design. These "concessions" appear to be necessary if a "serious" profession-oriented degree course is to be developed. Hence sub-disciplinary autonomy goes hand in hand with ambivalence, which is perceived as an external constraint, however, and shouldered collectively.

At the X-location, distinctions are notably clear in the master's degree and they arise from the controversial struggle over how representatives of sub-disciplines see themselves portrayed. Individual representatives of the discipline triggered this debate and: "then it became a sort of catalyst, 'aha, we have our own degree course ((laughingly)) with this clearly outlined sub-disciplinary profile' [...] and then the others (subject areas) began to weigh up the potential advantages" (X-location: 739ff.). The shared bachelor's degree course serves as the basis for "being able to go separate ways together" in master's degree (X-location: 1251). It seems, however, to be an almost forced collectivization, where sub-disciplinary autonomy in the master's degree is perceived as a "blow to freedom" (X-location: 845).

In the 'Establishing sub-disciplinary autonomy' type, educational science takes a back seat as a discipline in the face of pronounced sub-disciplinary orientations. Different disciplinary approaches for which there was no common ground or none had even been sought are dealt with via the autonomy and separation of degree courses.

When compared to older findings that still characterized German degree courses in educational science as a continuity and tradition-oriented "place of peaceful und quite work" (Hauenschild 1997: 787, own translation), the degree course design we find today is an arena where different disciplinary schools of thought struggle for their dissemination. However, this happens without necessarily referring to educational science in its plurality as the discipline as a whole. Furthermore, we can see that the strong differentiation of degree courses seen in our quantitative findings also refers to the immanent dynamics of fractured disciplines.

The change of the framework conditions for curriculum development, which is competition-oriented and whose kick-start was political (Bologna Reform), proves to be a catalyst for renegotiating disciplinary boundaries and institutionalizing them in degree courses.

As a result of the forced structural division of degree courses into bachelor's and master's degrees, the simultaneous introduction of New Public Management strategies and the growing influence of university management, the relationship between areas of scientific disciplines and the professional pedagogical fields of action as such is being challenged more and more by factors extraneous to the discipline. In group discussions, this proves to be a habitual action problem in degree course design across all cases and leads to a second type formation, which is outlined next.

\section{Dealing with Constraining Rule Expectations (Sense-Genetic Type Formation II)}

This second sense-genetic type formation draws attention to the collective ways of handling constraints on disciplinary orientations, which result from rule expectations by the university as an organization. Several thematic topics are relevant, such as guidelines for examination regulations, content and accreditation, human 
resources, and even ministerial resolutions. These aspects are formal rule expectations which face the disciplinary representatives in different ways at the universities.

Five different methods of coping with these constraining rule expectations were identified. While the pragmatism, resistance and compensation types have in common that they deal with these organizational barriers refer to their handling within the college rather than to the barriers themselves, the subversion and realignment types aim to alter these structural constraints. Given the volume limitation of this contribution, the resistance, compensation, subversion and realignment types are only briefly described, while the pragmatism type is presented in greater detail as an example. We focus on this type in more detail, because it is most appropriate to point out the underlying 'habitual' orientation problem of sense-genetic type formation as a whole and to describe the other types briefly and in a comprehensible way.

Regarding the pragmatism type, it is almost impossible to reconstruct collective orientation content that aims to assert disciplinary orientations that are contrary to the demands of the university. These demands are considered neither positive nor negative but rather followed in a more casual and pragmatic way. The following transcript is an illustration of this, taking up the example of organizational guidelines for teacher training that question the personnel capacities for the major degree course:

Cm: well we had exactly the opposite problem ((sufficient staff)). The university wanted to maintain and strengthen the didactics [...] and their in-house capacities, which is why we were ordered to add them in quotation marks to our degree courses, which means that our [...] students are now studying school subjects as well

Em: $m h m$

Cm:and bring along additional capacities.

Aw: $m h m$

Cm:the accreditation agency saw this as more of an oddity and gave the order to reduce it (C-location: 570-582)

The word "ordered" demonstrates that curricular requirements have a negative connotation and clearly contradict disciplinary orientations. This stipulation is not discussed, however, but implemented accordingly. A counter-reaction first emerges when external actors from the accreditation agency take a standpoint. In contrast to the interests of the university, curricular considerations from a disciplinary point of view are often expressed in the form of a proposal, which is subsequently adapted to the respective constraints. It is only implemented where there are no organizational constraints. In addition, challenges communicated via university rule expectations are dealt with on a degree course-specific basis and in smaller organizational units rather than collectively. Furthermore, it was also not possible to identify practices of collective action in other cases of this type to assert the orientations of the actors concerned. Despite their acceptance, organizational rule expectations are perceived as compulsory and force collective decision-making, which is in fact impossible. So, merging organizational units that are then obliged to design degree programmes together, for example, could be labelled as "it grows together which does not belong together" (P-location: 121-122). 
The way the representatives of the discipline in this type handle rule expectations is documented as an essentially pragmatic acceptance of university requirements. Although they are viewed as a problem according to their own common-sense theory, these requirements are casually absorbed into their actions. Furthermore, given the spectrum of disciplinary orientations that are difficult to reconcile, the handling of constraining rule expectations should be understood as the resigned acceptance of organizational and structural needs. These are addressed by smaller sub-disciplinary organizational units. This weary acceptance is based on the perception that human resources on site do not allow the representatives to adopt their own (sub-)disciplinary orientation framework. Given the organizational rule expectations and focusing on collective orientations for action, degree course design in this type is not about discipline-based decisions, but about subordinating disciplinary premises to structural requirements.

The resistance type, on the other hand, includes cases where degree course design has collective and clearly outlined disciplinary orientations. Moreover, this type regards organizational rule expectations as restrictive. As a result, in practice, action remains permanently tied to an orientation dilemma. It brings forth a subordination to constraints similar to the one that characterizes the pragmatism type, but it also means a retreat into smaller organizational units. Both, however, are coping mechanisms and not casual practice. Having to be active (so it is perceived) in degree courses that fail to correspond to the own disciplinary orientations fosters a resistant attitude, and the representatives go public about it. This collective opposition makes it possible to sound out further actions vis-à-vis structural limitations within the framework of collective (sub)disciplinary orientations.

In the third type, compensation, and similar to the previous types, limiting rule expectations are seen as established. However, they are perceived as editable and, contrary to the resistance type, lead to action that is not simply directed at overcoming the orientation dilemma, but also at the positive counter-horizon of professional and disciplinary orientations. The fact that human resources and the structural framework barely allow maintaining major degree courses or designing them in line with the ideals of faculty representatives leads to their increased personal commitment, compensating for the limitations they encounter.

In contrast to the three other types, the collective frameworks of orientation in the subversion and the realignment types is not only designed to deal with organizational rule expectations that curtail disciplinary orientations, but also to change them. Therefore, the orientation framework in the subversion type is directed at converting structural settings and content expectations on the part of the university into the positive counter-horizon. Given the different disciplinary orientations and the fluctuation of human resources, implementing disciplinary orientations decided collectively while facing university management's restrictive actions (or so they are perceived) only seems possible in stages. Here, juggling around with university rules and decision-making structures, e.g. using resources due to changes in course formats or occupy positions in influential committees of the academic governing body, is a method of implementing curricula that correspond to the disciplinary orientations of the disciplinary actors. 
In the realignment type, on the other hand, it is the existing degree courses that are predominantly seen as a restrictive organizational rule expectation and addressed as such. Changes to actor constellations due to newly appointed professorships or the retirement of older academics enable radical shifts in the hitherto firmly established degree course orientations that have been collectively supported by discipline representatives. New actors may also enable the enforcement of new disciplinary orientations. Emerging conflicts are either dealt with by 'playing' with a tailored personnel policy that leads to a degree course reorientation or are solved with the structural separation and implementation of different degree courses.

\section{Conclusion}

The strong differentiation and diversity of educational science degree courses identified in the quantitative sub-study initially appears to be the product of different disciplinary orientations and the boundaries drawn by the actors of a fractured discipline. The Bologna Process acts as a catalyst that enables these orientations to be implemented in different degree courses (Grunert 2012).

The qualitative findings, however, clearly reveal that these symbolic boundary-drawing practices (Lamont and Molnár 2002; Beer and Koenig 2009) are not produced by collective disciplinary orientations and beliefs alone. They are far more the expression of dynamic negotiation processes, where the power relations between the disciplinary actors play an important role. These are conducted not only with various attitudes to the disciplinary field of educational science (Hofstetter and Schneuwly 2010: 687f.) but are also suffused with pressures that stem from the organizational rule expectations from the university. The boundary-work practices are embedded both in the site-specific frameworks, as well as in the university, and in scientific and educational policy frameworks that accompany disciplinary processes of differentiation, transformation, displacement or dissolution (cf. Heinze and Münch 2012: 20f.; Beer and Koenig 2009: 4). It becomes clear that scientific disciplines and the university as an organization are combined to form a dynamic field of forces that generates curriculum development as a specific product of social construction (Karseth 2006; Barraud and Mignot-Gérard 2005; Jarzabkowski 2010). The changes to symbolic demarcations we identified derive from the multitude of labels of degree courses and profiles and they show shifts in this dynamic field and its underlying social and power relations. The analysis of the group discussions clearly indicated that - according to Fligstein and McAdam (2011, 2012) - higher education reform was an exogenous shock to the academic field and it set in motion the existing power structure and opened new spaces for action, notably with the demand for degree course design. In fractured disciplines, where there is little consensus on teaching content or, in the case of German educational science, on the orientation of the various professional fields, this room for manoeuvre seems far greater than in more consensual disciplines, such as medicine, mathematics or psychology and even as sociology, which at least in Germany can be seen more on the side of fractured disciplines (Grunert and Ludwig 2016). 
Table 1 Overview cases \& sense-genetic type formations I and II

Dealing with disciplinary heterogeneity

Dealing with constraining rule expectations

\begin{tabular}{lll}
\hline C-Location & Establishing sub-disciplinary autonomy & Pragmatism \\
D-Location & Establishing disciplinary standards & Compensation \\
H-Location & Anchoring disciplinary heterogeneity & Subversion \\
L-Location & Anchoring disciplinary heterogeneity & Compensation \\
P-Location & Establishing sub-disciplinary autonomy & Pragmatism \\
Q-Location & Anchoring disciplinary heterogeneity & Resistance \\
S-Location & Establishing disciplinary standards & Realignment \\
X-Location & Establishing sub-disciplinary autonomy & Realignment \\
Y-Location & Anchoring disciplinary heterogeneity & Subversion \\
Z-Location & Establishing sub-disciplinary autonomy & Resistance \\
\hline
\end{tabular}

In the case of fractured disciplines, negotiating a collective perspective on the discipline and the associated curriculum at each university is a fierce challenge. As the reconstruction of group discussions has shown, in German educational science this rarely takes place under the influence of external guidance to which all universities can adapt with mimetic processes (DiMaggio and Powell 1983). The role of scholarly associations of researchers and their recommendations for core curricula or degree course design is negligible; instead, we see evidence of site-specific negotiation processes, which in turn generate different patterns of disciplinary demarcation practices and are subsequently visible in degree courses. Bearing in mind the second type formation, this is linked to collective orientations towards and strategic practices to deal with organizational rule expectations, clearly pointing out that these processes are closely interwoven. At the same time - and explaining the existence of two sense-genetic type formations - this entanglement does not give rise to model patterns to deal with the two habitual action problems combined (cf. Tab. 1). In other words, there is no pattern that connects the types of one sense-genetic type formation with those of the other. Precisely this, however, can be understood as a possible expression of the specificity of fractured disciplines with weak boundaries (cf. Glaser and Keiner 2015). These are characterized by a comparatively rudimentary self-concept and have almost completely failed to develop standards for degree course design that are recognised by the discipline as a whole (cf. Horn 2014; Ludwig and Grunert 2020).

The twofold system logic of universities, science and education (Stichweh 1994: 175ff.), compels the actors involved in designing degree courses to find a balance between these two systems. As the findings show, this is all the more valid the more universities attempt to influence the design and profiling of the degree courses. Conversely, it is considerably less valid the more powerful the representatives of the discipline are and can participate in degree course design and the more consensual their disciplinary orientations at each university are. 
In this field of multidimensional challenges, the Bologna Reform can be seen as a catalyst for opening up room for action where disciplinary boundaries are questioned, modified and reshaped. With the restructuring and reorientation of degree courses, new standards are set, in turn allowing a shift in disciplinary power relations. In other words, disciplinary development is not merely the logical consequence of functional differentiation (Stichweh 1993). On the contrary, disciplines must be perceived as "historically variable structures of academic power relations" (Heilbron 2005: 24), whose actors move in a delicate field of organizational rule expectations, disciplinary policy, public and academic recognition, and individual or collective academic and career-related interests. In this light, degree courses are an expression of these dynamics as they unfold in their respective historical situation, where different actor constellations produce different symbolic boundary-drawing practices, and disciplinary order can be renegotiated. That this phenomenon seems more dynamic in fractured disciplines than in others of a more consensual and consistent nature is not to deny the potential significance of similar dynamics for these disciplines (cf. e.g. Abele-Brehm et al. 2014 for Psychology in Germany). Exploring this, however, must be left to future disciplinary comparative research.

Overall, it becomes clear that in the field of tension between disciplinary orientation and organizational expectations of rules in curriculum development, disciplinary representatives in fractured disciplines hardly (can) refer to disciplinary guiding principles as instruments of orientation and power to assert their interests. This seems to be an important aspect, not least, in the question of the extent to which disciplines lose power in defining their own curricula, given the rise of a "governance structure that implies more direct control over curriculum content and assessment" (Karseth and Solbekke 2016: 229). In addition, the question arises for fragmented disciplines in particular as to what consequences heterogeneity already at the level of subject designations entails for their own visibility in the higher education context and beyond. It is also important to ask what resources the disciplinary associations can provide to strengthen the position of the discipline representatives at the universities so that they can act on the basis of disciplinary standards with regard to content, structural and financial requirements instead of leaving this to individual coincidence.

In this sense, on the one hand, "academics must become more aware of the influence of political priorities" (ibid.: 230) and of the university as an organization on curriculum design in the future. On the other hand, more attention should also be paid in terms of discipline policy to the role that the engagement of disciplinary associations can play in mediating between discipline and organization in order to strengthen the position of discipline representatives vis-à-vis universities and also in accreditation procedures.

Funding Open Access funding enabled and organized by Projekt DEAL.

Open Access This article is licensed under a Creative Commons Attribution 4.0 International License, which permits use, sharing, adaptation, distribution and reproduction in any medium or format, as long as you give appropriate credit to the original author(s) and the source, provide a link to the Creative Commons licence, and indicate if changes were made. The images or other third party material in this article 
are included in the article's Creative Commons licence, unless indicated otherwise in a credit line to the material. If material is not included in the article's Creative Commons licence and your intended use is not permitted by statutory regulation or exceeds the permitted use, you will need to obtain permission directly from the copyright holder. To view a copy of this licence, visit http://creativecommons.org/licen ses/by/4.0/.

\section{References}

Abbott, Andrew. 2001. Chaos of disciplines. Chicago: Chicago University Press.

Abele-Brehm, Andrea, Markus Bühner, Roland Deutsch, Edgar Erdfelder, et al. 2014. Bericht der Kommission „Studium und Lehre“ der Deutschen Gesellschaft für Psychologie. Psychologische Rundschau 65(4): 230-235.

Ambrose, Don, Joyce VanTassel-Baska, Laurence J. Coleman, and Tracy L. Cross. 2010. Unified, insular, firmly policed, or fractured, porous, contested, gifted education? Journal for the Education of the Gifted 33(4): 453-478.

Austermann, Simone, Judith Freitag, Peter Vogel, and Lothar Wigger. 2004. Kerncurriculum Erziehungswissenschaft. Konzepte und Erfahrungen. Erziehungswissenschaft 15(28): 37-48.

Barraud, Pauline and Stephanie Mignot-Gérard. 2005. The Implementation of the Bachelor Master Study Structure in French Universities. A European Reform in the hands of Academic Tribes. Bergen.

Beer, Bettina, and Matthias Koenig. 2009. Grenzziehungen im System wissenschaftlicher Disziplinen der Fall der „Kulturwissenschaft(en)“. Sociologia Internationalis 47(1): 3-38.

Biesta, Gert. 2016. Who's afraid of teaching? Heidegger and the question of education ('Bildung'/'Erziehung'). Educational Philosophy and Theory 48(8): 832-845.

Bohnsack, Ralf. 2010. Documentary Method and Group Discussions. In Qualitative Analysis and Documentary Method in International Education Research, eds. Ralf Bohnsack, Nicolle Pfaff, and Wivian Weller, 99-124. Opladen: Barbara Budrich.

Bologna Declaration. 1999. Joint Declaration of the European Ministers of Education. Bologna: The European Space for Higher Education.

Bortz, Jürgen. 2005. Statistik für Human- und Sozialwissenschaftler. Heidelberg: Springer Medizin.

Bourdieu, Pierre. 1998. Vom Gebrauch der Wissenschaft: für eine klinische Soziologie des wissenschaftlichen Feldes. Konstanz: UVK.

DGfE=Deutsche Gesellschaft für Erziehungswissenschaft (Eds.). 2010. Kerncurriculum Erziehungswissenschaft. Empfehlungen der Deutschen Gesellschaft für Erziehungswissenschaft (DGfE). $2^{\text {nd }}$ edition. Opladen and Farmington Hills: Barbara Budrich.

DiMaggio, Paul J., and Walter W. Powell. 1983. The iron cage revisited. Institutional isomorphism and collective rationality in organizational fields. American Sociological Review 48: 147-160.

Krüger, Heinz-Hermann, Thomas Rauschenbach, Kirsten Fuchs, Cathleen Grunert, et al. 2003. DiplomPädagogen in Deutschland. Survey 2001. Weinheim, München: Juventa.

Glaser, Edith and Edwin Keiner (eds.). 2015. Unscharfe Grenzen - eine Disziplin im Dialog. Pädagogik, Erziehungswissenschaft, Bildungswissenschaft, Empirische Bildungsforschung. Bad Heilbrunn: Klinkhardt.

Fligstein, Neil, and Doug McAdam. 2011. Toward a General Theory of Strategic Action Fields. Sociological Theory 29(1): 1-26.

Fligstein, Neil, and Doug McAdam. 2012. A theory of fields. Oxford: Oxford University Press.

Früh, Werner. 2017. Inhaltsanalyse: Theorie und Praxis. München: UVK.

Fuchs, Peter. 2007. Die soziologische Beobachtung der Erziehungswissenschaft. In Zwischen Reflexion, Funktion und Leistung: Facetten der Erziehungswissenschaft, ed. Volker Kraft, 69-82. Bad Heilbrunn: Klinkhardt.

Gieryn, Thomas F. 1983. Boundary-work and the demarcation of science from non-science: strains and interests in professional ideologies of scientists. American Sociological Review 48(6): 781-795.

Gieryn, Thomas F. 1994. Boundaries of science. In Handbook of science, technology and society, eds. Sheila Jasanoff, Gerald E. Markle, James C. Petersen, and Trevor Pinch, 393-443. Thousand Oaks: Sage Publications. 
Goldmann, Daniel. 2017. Gruppe, Milieu, Organisation - Begriffliche und empirische Reflexionen der dokumentarischen Organisationsforschung. In Dokumentarische Organisationsforschung. Perspektiven der praxeologischen Wissenssoziologie, eds. Steffen Amling and Werner Vogd, 146-164. Opladen: Barbara Budrich.

Goodson, Ivor F. 1997. The Changing Curriculum. Studies in Social Construction. New York: P. Lang.

Grunert, Cathleen. 2012. Erziehungswissenschaft im Spiegel ihrer Studiengänge. Die Studienreform und ihre Folgen für die Disziplin. Zeitschrift für Erziehungswissenschaft 15(2): 573-596.

Grunert, Cathleen, and Katja Ludwig. 2016. Disziplinen im Wandel? Erziehungswissenschaft und Soziologie im Bologna-Prozess. Zeitschrift Für Pädagogik 62(6): 886-908.

Grunert, Cathleen, Katja Ludwig and Kilian Hüfner. 2020. Studiengänge und Standorte im Hauptfach. In Datenreport Erziehungswissenschaft 2020, eds. Hermann Josef Abs, Harm Kuper, and Renate Martini, 21-50. Opladen: Barbara Budrich.

Hauenschild, Helga. 1997. Zur sozialwissenschaftlichen Wendung im erziehungswissenschaftlichen Lehrangebot. Zeitschrift Für Pädagogik 43(5): 771-789.

Hechler, Daniel, and Peer Pasternack. 2012. Hochschulorganisationsanalyse zwischen Forschung und Beratung. Sonderband ,die hochschule“ 2012. Halle-Wittenberg.

Heilbron, Johan. 2005. Das Regime der Disziplinen. Zu einer historischen Soziologie disziplinärer Wissenschaft. In Interdisziplinarität als Lernprozess. Erfahrungen mit einem handlungstheoretischen Forschungsprogramm, eds. Hans Joas, and Hans G. Kippenberg, 23-46. Göttingen: Wallstein.

Heinze, Thomas, and Georg Krücken (eds.). 2012. Institutionelle Erneuerungsfähigkeit der Forschung. Wiesbaden: Springer VS.

Heinze, Thomas, and Richard Münch. 2012. Intellektuelle Erneuerung der Forschung durch institutionellen Wandel. In Institutionelle Erneuerungsfähigkeit der Forschung, eds. Thomas Heinze and Georg Krücken, 15-38. Wiesbaden: Springer VS.

Hofstetter, Rita, and Bernhard Schneuwly. 2010. Erziehungswissenschaft als Gegenstand der Historiographie. Eine Disziplin im Spannungsgebiet disziplinärer, professioneller und lokaler/(inter)nationaler Felder. Zeitschrift für Pädagogik 56(5): 678-702.

Horn, Klaus-Peter. 1999. Die Diskussion um ein Kernstudium der Erziehungswissenschaft in den 60er Jahren. Zeitschrift Für Pädagogik 45(5): 749-758.

Horn, Klaus-Peter. 2014. Pädagogik/Erziehungswissenschaft der Gegenwart. Zur Entwicklung der deutschen Erziehungswissenschaft im Spiegel ihrer disziplinären Selbstreflexion (1910-2010). In Das Selbstverständnis der Erziehungswissenschaft. Geschichte und Gegenwart, eds. Reinhard Fatke, and Jürgen Oelkers (Zeitschrift für Pädagogik, 60. Beiheft), 14-32. Weinheim: Beltz Juventa.

Huber, Ludwig. 1991. Fachkulturen. Über die Mühen der Verständigung zwischen den Disziplinen. Neue Sammlung 31(1): 3-24.

Hüther, Otto. 2012. Wandelbarkeit von Forschungsstrukturen in deutschen Universitäten. Eine Analyse der Landeshochschulgesetze. In Institutionelle Erneuerungsfähigkeit der Forschung, eds. Thomas Heinze, and Georg Krücken, 127-155. Wiesbaden: Springer VS.

Jarzabkowski, Paula. 2003. Strategic Practices: An Activity Theory Perspective on Continuity and Change. Journal of Management Studies 40(1): 23-55.

Jarzabkowski, Paula. 2010. An activity-theory approach to Strategy as Practice. In Cambridge Handbook of Strategy as Practice, eds. Daniel Golsorkhi, Linda Rouleau, David Seidl, and Eera Vaara, 127140. Cambridge: Cambridge University Press.

Karseth, Berit. 2006. Curriculum Restructuring in Higher Education after the Bologna Process. Revista Española De Educación Comparada 12: 255-284.

Karseth, Berit, and Tone Dyrdal Solbrekke. 2016. Curriculum Trends in European Higher Education: The Pursuit of the Humboldtian University Ideas. In Higher Education, Stratification, and Workforce Development, eds. Sheila Slaughter, and Barrett Jay Taylor, 215-233. Cham, Heidelberg, New York, Dordrecht, London: Springer.

Keiner, Edwin. 2015. Pädagogik, Erziehungswissenschaft, Bildungswissenschaft. Empirische Bildungsforschung - Begriffe und funktionale Kontexte. In Unscharfe Grenzen - eine Disziplin im Dialog, eds. Edith Glaser, and Edwin Keiner, 13-34. Bad Heilbrunn: Klinkhardt.

Keiner, Edwin, and Sarah Schauffler. 2014. Disziplinäre und organisatorische Grenzen, Überschneidungen und Neuformatierungen. Das Beispiel Pädagogische Psychologie und Erziehungswissenschaft. In Die Idee der Universität - revisited, eds. Norbert Ricken, Hans-Christoph Koller, and Edwin Keiner, 269-301. Wiesbaden: Springer VS.

Klatetzki, Thomas. 2012. Professionelle organisationen. In Handbuch Organisationstypen, eds. Maja Apelt and Veronika Tacke, 165-183. Wiesbaden: Springer VS. 
Krüger, Heinz-Hermann. 2012. Einführung in Theorien und Methoden der Erziehungswissenschaft. Opladen: Barbara Budrich.

Kuhn, Thomas S. 1989[1962]. Die Struktur wissenschaftlicher Revolutionen. Frankfurt am Main: Suhrkamp.

Lamont, Michèle, and Virág Molnár. 2002. The Study of Boundaries in the Social Sciences. Annual Review of Sociology 28(1): 167-195.

Ludwig, Katja. 2019. „Es war ein Ringen“-Zum Umgang mit disziplinärer Heterogenität im Kontext der Entwicklung erziehungswissenschaftlicher Hauptfachstudiengänge. Zeitschrift Für Erziehungswissenschaft 22(2): 461-479.

Ludwig, Katja, and Cathleen Grunert. 2018. „Über die Früchte [... “ der Bologna-Reform. Rekonstruktionen zur Gestaltung erziehungswissenschaftlicher Hauptfachstudiengänge zwischen Disziplin und Hochschule. In Wendungen und Windungen in der Erziehungswissenschaft. Empirische Studien, eds. Katharina Vogel, Christiana Bers, Johanna Brauns, Anne Hild, Anna Stisser, and Klaus-Peter Horn, 83-105. Bad Heilbrunn: Klinkhardt.

Ludwig, Katja, and Cathleen Grunert. 2020. Studiengangsentwicklung als Ausdruck disziplinärer Wandlungsprozesse? Erziehungswissenschaft zwischen fachgesellschaftlichen Empfehlungen und ausdifferenzierter Studiengangslandschaft. In Strukturwandel der Erziehungswissenschaft und der erziehungswissenschaftlichen Wissensproduktion, eds. Ulrich Binder, and Wolfgang, 109-124. Bad Heilbrunn: Klinkhardt.

Luhmann, Niklas. 2002. Das Erziehungssystem der Gesellschaft. Frankfurt am Main: Suhrkamp.

Meyer, John W., and Brian Rowan. 1977. Institutionalized Organizations: Formal Structure as Myth and Ceremony. American Journal of Sociology 83(2): 340-363.

Musselin, Christine. 2007. Are Universities Specific Organisations? In Towards a Multiversity?, eds. Georg Krücken, Anna Kosmützky, and Marc Torka, 63-84: Bielefeld: transcript.

Nohl, Arnd-Michael. 2010. Narrative Interview and Documentary Interpretation. In Qualitative Analysis and Documentary Method in International Education Research, eds. Ralf Bohnsack, Nicolle Pfaff, and Wivian Weller, 195-217. Opladen: Barbara Budrich.

Pellert, Ada. 1999. Die Universität als Organisation. Die Kunst, Experten zu managen. Wien: Böhlau.

Bohnsack, Ralf, Nicolle Pfaff, and Wivian Weller (eds.). 2010. Qualitative Analysis and Documentary Method in International Education Research. Opladen: Barbara Budrich.

Ruhloff, Jörg. 2006. Warum Erziehungswissenschaft als Disziplin? In Perspektiven Allgemeiner Pädagogik, ed. Johannes Bellmann, et al., 33-44. Weinheim: Beltz.

Steinhardt, Isabel. 2015. Lehre stärkt Forschung. Studiengangentwicklung durch ProfessorInnen im Handlungssystem Universität. Wiesbaden: Springer VS.

Stichweh, Rudolf. 1993. Wissenschaftliche Disziplinen: Bedingungen ihrer Stabilität im 19. und 20. Jahrhundert. In Sozialer Raum und akademische Kulturen, eds. Jürgen Schriewer, Edwin Keiner, and Christophe Charle, 235-250. Frankfurt am Main: Peter Lang.

Stichweh, Rudolf. 1994. Wissenschaft, Universität, Professionen. Soziologische Analysen. Frankfurt am Main: Suhrkamp.

Teichler, Ulrich. 2016. Bologna - ein normaler Schritt der Studienreform oder ein unerwarteter Systemwechsel? In Wissenschaft mit Zukunft. Die alte Kölner Universität im Kontext der europäischen Universitätsgeschichte, eds, Andreas Speer and Andreas Berger, 397-429. Köln: Böhlau.

Wagner-Winterhager, Luise. 1990. Neuere Entwicklungen in den wissenschaftlichen Diplomstudiengängen Erziehungswissen-schaft/Pädagogik. Erziehungswissenschaft 1(1): 44-66.

Publisher's Note Springer Nature remains neutral with regard to jurisdictional claims in published maps and institutional affiliations. 